\title{
Research on University Art Teaching Reform under the Information Environment
}

\author{
Xukun Luo \\ Yunnan Technology and Business University, Kunming Vocational Education Park, Kunming, Yunnan, \\ 651701
}

Keywords: University Art; Informationization; Teaching Reform

\begin{abstract}
With the further deepening of education reform, the combination of information technology and education has become more and more close, and the integration of information technology in university art teaching has become an important force to promote the development of teaching reform. The traditional art teaching method is relatively rigid, and the presentation of art knowledge is relatively simple. The initiative of students' learning is restrained. Under the background of the development of information technology, information technology has a great influence on the reform and development of university art teaching. This paper first expounds the characteristics of university art teaching and the advantages of information technology application in the information environment, then analyzes the application basis and key points of information technology reform in art education, and finally explores the status quo of university art teaching reform and the detailed exploration of reform strategies in the information environment. With the help of this theoretical research, it is hoped to provide a certain inspiration for the reform and development of university art teaching.
\end{abstract}

\section{Introduction}

College art courses are important courses for cultivating students' comprehensive quality. Art has positive significance for purifying people's minds and beautifying people's thoughts. In the development of university art teaching, it is necessary to pay full attention to improving teaching quality and promoting the development of students' comprehensive quality. In the information environment, the reform of university art teaching is becoming more and more important. The application of information technology provides technical support for the development of university art teaching, which has become an important driving force for students' learning and development. Through the theoretical research on the application of information technology, this application of information technology can provide a corresponding reference.

\section{The Characteristics of University Art Teaching and the Advantages of Information Technology Application in the Information Environment}

\subsection{Characteristics of College Art Teaching under the Information Environment.}

University art teaching and traditional teaching in the information environment are different, showing new characteristics, reflected in the teaching autonomy. The content of the art curriculum is constantly enriched with the development of the times, the art knowledge and skills are also changing, and the methods of knowledge and skills and the ways of obtaining have also changed. These have had a great impact on the art teaching of the university. [1]. In the information environment, the application of information technology provides great convenience for university art teaching, making art teaching more independent and students' learning more independent. This provides convenience for students to learn online knowledge and promote it. The leading role of art teaching has been played, which has effectively improved the quality of art teaching.

The characteristics of university art teaching in the information environment are also relatively distinct, mainly the diversification of educational value. In the traditional art teaching, the teaching 
of art knowledge and skills is more concerned, but the lack of attitudes towards students' art learning and the cultivation of emotions and other qualities make the students' comprehensive quality of art not high. And the standards of art teaching are also relatively singular, which is not conducive to the study of students' art knowledge. Under the information environment, the standard of university art teaching and the variety of learning content allow students to choose their own learning style according to their own characteristics.

Under the information environment, the characteristics of university art teaching are more prominent in the characteristics of openness. Due to the limitations of teaching places and learning time, the overall efficiency of traditional art teaching is relatively low. The environment of art teaching in the information environment is relatively open, no longer limited by time and place, and the content of teaching is also rich. The content of art teaching is more abundant. Teachers and students can more objectively understand and evaluate themselves. In the open information environment, the status between teachers and students has also changed. The subjective status of students can be clearly presented in the classroom, and the leading role of teachers can be well developed.

The characteristics of university art teaching in the information environment are also reflected in the aspect of interactivity, which is different from traditional art teaching. Art teaching in the information environment can present art knowledge through the use of various carriers, and can enhance communication between teachers and students. Teachers can use information technology to present art knowledge and communicate with students, which can effectively increase the interactivity of teaching. This has a positive significance for students to learn art knowledge [2].

\subsection{University Art Teaching Information Technology Application Advantages.}

The application of information technology in university art teaching has many advantages. Through information technology, it can greatly enrich the content of art teaching and broaden students' understanding of art knowledge. This provides convenience for students to learn art knowledge and understand art knowledge from multiple angles. The use of information technology can guide students to actively explore the problems in art knowledge learning, inspire students' creative thinking, and promote students' learning efficiency. The art knowledge in the network is massive, which provides convenience for solving problems in the study of students' art knowledge, and can also stimulate students to further deepen into the study of art knowledge [3]. Under the background of further education reform, the integration of information technology and art teaching is a trend, which has promoted the space and time and place constraints of teaching, providing students with more open art resources and broadening students' knowledge of art. The breadth and depth of understanding guides students' multi-level and information development.

The application of information technology in university art teaching also reflects the intuitive advantage of teaching, which is different from traditional art teaching. In the art teaching, students can understand the perspective principle through the application of information technology, and present some works to students dynamically. Observing different perspective principles from different angles can visually bring students an intuitive impact and strengthen students. The depth and breadth of cognition of art knowledge helps to improve the goal of art teaching. Some contents in art teaching cannot be presented to students by adopting traditional teaching methods, such as planning model design content. Through the application of information technology, 3D software can be used to present planning models for students, which can improve the efficiency of art teaching and quality.

The application of information technology in university art teaching is reflected in the active atmosphere of the classroom and the initiative of students to learn. The application of information technology can apply a variety of art knowledge presentation carriers, and present the content of art teaching through the use of dynamic image and sound and image carrier [4]. There are also abstract knowledge points in art teaching. The traditional teaching methods are more rigid and can not stimulate students' active learning. Under the application of information technology, they can use rich and dynamic images and match vivid and beautiful music. Etc., let students feel the beauty of 
art knowledge through multi-sensory mobilization, and let students learn actively in an active learning environment.

The advantages of the use of university art teaching information technology are reflected in the ability to improve students' aesthetic ability, and guide students to enter the special atmosphere of art works under the use of rich form-and-sound information, giving students an immersive experience. Beauty has a positive meaning. When enjoying the landscape painting, the teacher can use the multimedia technology to play the songs such as "Mountain Flowing Water" or "Fishing Boat Singing Evening" to create a sense of tranquility and long-distance for students, and to stimulate students' imagination of the artistic conception of the works, which has the ability to improve students' aesthetic ability.

\section{The Application Basis and Main Points of Information Technology in Art Education Reform under the Information Environment}

In the information environment, the application of information technology in the art teaching reform has its foundation. At present, the software and hardware equipment of the university has been gradually completed. The application hardware conditions of information technology in university art teaching are basically perfect, and the application of computers is increasing. The more the combination of information technology and art teaching, has become an important force in promoting the reform and development of art teaching. The application of various teaching software is more and more extensive, which provides a rich resource for art teaching and brings great convenience to art teaching [5]. In the application of information technology in art teaching, the teaching ability of teachers themselves has been continuously improved, and the ability to apply information technology teaching has been established. This has laid the foundation for the integration of information technology and art teaching. The students also have the basic qualities of information technology and art teaching integration. The current students are familiar with information technology and are also in line with the characteristics of students' learning. The use of information technology in art teaching has a positive effect on stimulating students' enthusiasm for learning. It can provide students with an open teaching environment, which is more conducive to the further development of art teaching.

In the reform of university art teaching in the information environment, we must pay attention to several points in the application of information technology. Art is a special subject, we must prepare in the teaching, scientifically design the art courseware, and prepare the necessary information. Teachers themselves should make good use of information technology to build a database, starting from the usual resource collection and organization work, storing excellent art works in the computer in time, or purchasing a corresponding amount of material material CDs for animation and video recording. In this way, information technology is applied as a tool to present more resources for art learning knowledge for students.

The art teaching in the information environment should be combined with the traditional teaching media, and the mutual complementation of the two can better improve the quality of art teaching. In the information environment, the preparation of art teaching and the appropriateness of information technology application should be paid attention to in the teaching. The application of information technology should be based on the convenience of students learning art knowledge, so that students can better master the art knowledge. The application of information technology is not applicable to every link and content, so teachers should choose the specific conditions of art teaching to avoid negative effects.

\section{The Status Quo and Reform Strategy of College Art Teaching Reform under the Information Environment}

\subsection{Current Situation of College Art Teaching Reform under the Information Environment.}

There are still many shortcomings in the reform and development of university art teaching in 
the information environment, which affects the quality of teaching. In the art teaching, some teachers do not have a strong sense of using information technology. They do not change the teaching concept in time. They still use the traditional indoctrination teaching mode. They do not pay attention to the subject status of students in the classroom. Students are passive when learning art knowledge. The location is relatively low in learning efficiency. The new curriculum standards have higher requirements for art teaching, pay attention to the cultivation of students' comprehensive quality, and have new requirements in the innovation of teaching [6]. In the actual university art teaching, the application of information technology is still more prominent, which is not conducive to the further development of art teaching. Faced with the increasingly complex teaching development environment, the integration and development of university art teaching and information technology has become an inevitable trend. It is necessary to actively respond to this and reverse the current unfavorable teaching development.

\subsection{The Reform Strategy of College Art Teaching under the Information Environment.}

The reform of university art teaching in the information environment should be closely integrated with the actual development requirements, and fully focus on the pertinence of strategy implementation, which can be considered from the following aspects:

First, strengthen the construction of information technology infrastructure for art teaching. The development of art teaching in the information environment needs to start from the aspect of information infrastructure construction, which is an important basic content of the role of information technology. The university leadership should pay full attention to the important value and significance of information technology to art teaching, further strengthen the investment in the construction of information infrastructure, provide power for the information development of art teaching, establish multimedia network classrooms, and share network resources. The goal is to achieve technical support for students to learn art knowledge through the use of network technology. In the construction of information software and hardware, we must pay attention to the diversified presentation of functions, the monitoring function of multimedia classrooms, and the broadcast function and broadcasting function, all of which must be possessed to lay a solid foundation for the development of university art teaching.

Second, the use of art teaching network resources. In order to improve the quality level of university art teaching, it is necessary to pay full attention to the scientific use of network resources. During the period of information development, the university's informatization construction has also accelerated its speed. In the development of art teaching, the use of network resources has become an important measure to improve the quality of teaching, paying full attention to the scientific application of online art resources, thus ensuring the development of art teaching. . The multimedia teaching network can provide students with dynamic knowledge and rich and colorful art knowledge. The use of network technology also supports students' independent learning. The network is a resource library. On the basis of scientific selection of art learning resources, It has a positive effect on the broad horizons of students.

Third, the use of art online teaching mode. The application of information technology provides more possibilities for university art teaching, especially in the openness of teaching. Online art teaching has many forms, among which online teaching and interest-based teaching and comprehensive teaching modes are different from traditional teaching. For example, in the mode of online art teaching, teachers can use the network to conduct real-time teaching for students. The information transmission and feedback in teaching are relatively straightforward. Students can also ask students questions in time, and the interaction between teachers and students can be obtained. Strengthened. The use of offline teaching mode is also more important. Teachers send offline teaching materials to students through the network. After receiving materials, students can learn at non-Internet time, and network application efficiency can be improved by bears [7]. In the art teaching, teachers use the teaching method of multimedia network technology, the teaching presentation mode is more common. The teacher presents the art teaching content to the students in the form of audio-visual materials through the resource library, so that the students can learn. There 
is also an interactive video teaching method, through the use of multimedia devices and student interaction learning, which has a positive significance for improving the quality of student learning.

Fourth, focus on the good establishment of teacher-student relationship. In the implementation of university art teaching reform under the information environment, in order to improve the quality of teaching reform, it is necessary to strengthen the emphasis on the implementation of specific measures, and strengthen the establishment of a new teacher-student relationship is the basis for guaranteeing the quality of teaching. Under the information environment and the implementation of teaching reform, it has been very different from traditional teaching. Especially in the relationship between teachers and students, we must pay attention to the establishment of equal interaction and cooperative teacher-student relationship, and carry out art teaching activities around students. It is necessary to update the teaching concept in a timely manner, pay attention to the application of information technology and strengthen communication with students, understand the learning situation of students, and then formulate corresponding teaching plans and strategies in a targeted manner, so as to help improve the overall quality of art teaching.

\section{Conclusion}

All in all, the use of information technology in university art teaching has become a trend. The application of information technology needs to be further deepened. It should be consistent with the direction of teaching reform and improve the overall level of information technology application. Under the above research on the application of information technology in college art teaching, I have a deeper understanding of the art teaching informatization from the theoretical level, hoping to benefit the actual teaching.

\section{References}

[1] Xu Wei, Anna. Research on the effect of art appreciation teaching and information technology integration [J]. Popular Literature and Art. 2016(21)

[2] Li Chaochao, Liu Gong. Case Study on the Integration of Art Teaching and Information Technology in Middle Schools [J]. Journal of Changchun Teachers College. 2017(02)

[3] Xu Yan. Discussion on the effective integration of information technology and art teaching [J]. Gakuen (Educational Research). 2017(11)

[4] Zhang Chong. On the Integration of Information Technology and Art Discipline [J]. Education and Teaching Forum. 2017(24)

[5] Liu Fang. Research on Art Appreciation Teaching in Information Technology Environment [J]. Education and Occupation. 2017(09)

[6] Zhang Li. Information Technology Inserts the Wings of Art Classroom Teaching [J]. China Educational Technology Equipment. 2017(07)

[7] Cui Ming, Wu Qing. On the integration of modern network information technology and art teaching [J]. Science and Education Wenhui (mid-season). 2018(02) 